Розділ III. Історичні та порівняльні аспекти в теорії і практиці духовно-інтелектуального виховання й навчання

\title{
РОЗВИТОК ПАТРІОТИЗМУ В ДІТЕЙ У КНР
}

\section{Жерновникова О. А.}

доктор педагогічних наук, професор, завідувач кафедри математики, Харківський національний педагогічний університет імені Г. С. Сковороди, м. Харків, Україна

\section{Чень Цзін}

здобувач третього (освітньо-наукового) рівня вищої освіти кафедри початкової і професійної освіти, Харківський національний педагогічний університет імені Г.С. Сковороди, м. Харків, Україна

У статті розглядаються загальні та специифічні підходи до проблем патріотичного виховання дітей в Китаї. Авторами зазначено, щуо вирішення проблем патріотичного виховання вимагає не тільки теоретичного опрацювання, але й відповідного програмного забезпечення, щзо грунтуються на громадянській позищї та патріотичному настрої.

Ключові слова: патріотичне виховання, патріотизм, діти, засоби патріотичного виховання.

The article considers general and specific approaches to the problems of patriotic upbringing of children in China. The authors note that solving the problems of patriotic education requires not only theoretical elaboration, but also appropriate software based on civic position and patriotic mood.

Key words: patriotic education, patriotism, children, means of patriotic education.

Розвиток будь-якої держави безпосередньо пов'язано з тим, що має закладатися у фундаментальну підготовку дітей. Невипадково політики, громадські діячі, соціологи, педагоги та інші фахівці постійно повторюють, що саме підростаюче покоління може забезпечити наступність та прогресивну зміну будь-якого суспільства.

У словниках наводяться різні тлумачення слова «патріотизм». Так, у словнику С. Гончаренка це поняття розкривається як любов до своєї батьківщини, відданість своєму народу та відповідальність перед ним в ім'я інтересів своєї Батьківщини [2, с. 345].

Саме в дитячому віці закладається основа, яка в подальшому має вплив на розвиток індивіда: ставлення до місця проживання, до батьківщини, до оточуючих людей, до найближчої спільноти, до себе як 
частини цієї спільноти тощо. О. Коваленко та О. Жерновникова зазначають, що «дорослий вводить дитину у світ соціальної дійсності суспільно вироблених навичок, умінь, способів практичної діяльності, моралі тощо. А оскільки у предметах матеріальної та духовної культури та iї традиціях знаходять своє втілення історично сформовані форми психічного життя людей, то дитина, пізнаючи культуру та опановуючи нею, разом з тим самим засвоює і ці форми; на цій основі у нього розвиваються специфічні соціальні форми психіки» [1, с. 26]. Тому важливо, щоб дитячі переживання, що породжуються подіями, що відбуваються, з одного боку, були засвоєні дітьми як первинна основа події, соціалізації, з другого - супроводжувалися позитивними емоційними підкріпленнями, що у сукупності створює базис для формування і матеріальних, і моральних цінностей, яких, безумовно, ставляться і патріотичні почуття.

Схожі підходи до розуміння значущості патріотичного виховання у дитячому віці виявляються й у педагогіці Китаю. Так, ще 1991 р. голова Китайської Народної Республіки (КНР) Цзян Цземінь висунув тезу про необхідність організації патріотичного виховання від дитячого садка до університету, наголошуючи, що патріотизм є важливим компонентом побудови духовності нації [3].

У КНР до питань патріотичного виховання також зверталися такі вчені, як-от: Чжан Сяо Ін, Лі Цзядао, Чжао Сюй Мей, Цзян Ші Мей, Лю Ін, Хе Хуй Цзюнь, Цзян Юй Хун. У своїх роботах дослідники писали про важливість патріотичного виховання, про необхідність приділяти цьому питанню особливу увагу в освітньому процесі. Зокрема, Чжан Сяо наполягає на необхідності здійснювати патріотичне виховання у повсякденній діяльності дітей. Також автор зазначає про важливість знайомства дітей з рідним містом та його пам'ятками [4].

Для вчених очевидно, що патріотичне виховання - це не епізод, не разова акція, а цілеспрямований, систематичний процес, що впливає на усвідомлення, прийняття та подальшу трансляцію суспільно та особистісно значущих цінностей, пов' язаних із місцем проживання, з країною, в якій відбувається формування особистості, що сприяє духовному осягненню батьківщини як мікро- і макросоціуму, усвідомлення себе та свого призначення, місця у цьому соціумі. Тому патріотичне виховання має здійснюватись $з$ дитинства. Установки, відображені в дошкільному віці, значно впливають на вибір життєвого шляху людини. 
Розділ III. Історичні та порівняльні аспекти в теорії і практиці духовно-інтелектуального виховання й навчання

Отже, патріотичне виховання як значущий напрям має бути відображено у програмному забезпеченні освітнього процесу закладів освіти.

Так, Лі Цзядао зазначає про те, що починати цю роботу необхідно з звернення саме до патріотичних почуттів дітей для того, щоб діти любили та поважали свою Батьківщину. Любов та повага до Батьківщини розкривається через почуття до своєї родини, близьких та оточуючим людям. Виховувати патріотизм необхідно через рідну природу краю, своє місто, мистецтво та культуру нації, тобто. через навколишнє середовище дитини. Лі Цзядао висуває два принципи патріотичного виховання: знайомство з інформацією за принципом від близької та зрозумілої дитини до більш складної та незрозумілої; та участь дорослих, які повинні подавати приклад патріотизму, показувати свою любов та повагу до Батьківщини [3].

Досить цікавим для цього дослідження є підхід Цзян Юй Хун, який говорить про важливість правильного розуміння патріотичного виховання. На думку вченого, патріотичне виховання — це формування в дітей віком позитивних емоцій і почуттів. Автор вказує, що найчастіше педагоги дитячого садка сприймають патріотичне виховання як знайомство дітей з прапором, гербом та іншими символами країни та нації. На думку Цзян Юй Хун, патріотизм — це любов до людей, до рідного міста та до Батьківщини. Педагогам дитячого садка необхідно виховати у дітей любов до навколишнього насправді.

Як показує практика, педагоги, впроваджуючі програми патріотичного виховання, найчастіше апелюють до наочно-образному мисленню дітей, ставлячи завдання залишити у свідомості дитини певні образи, пов'язані з батьківщиною, місцем проживання, сформувати позитивне емоційне ставлення до них, організувати якусь діяльність, що дозволяє оперувати цими образами, що сприяє усвідомленню їх значення, закріплення в образі світу дитини.

Умовно можна позначити ці образи як певні індикатори (тобто доступні спостереженню та вимірюванню характеристики [1]), що знаходяться в зоні найближчого розвитку дитини та пов'язані з патріотичною тематикою. До таких індикаторів (подібних показників) можуть належати державна символіка (прапор, герб тощо), продукти народного промислу (іграшки, вироби, деталі) національного костюма) тощо. 
Отже, патріотизм розглядається як базова складова самосвідомості народу, що виражається в почуттях любові, гордості та відданості своїй вітчизні, ïi історії, культурі, традиціям та побуту, також у визнанні його самобутності та самоцінності, у необхідності їі захисту. Найважливішим, на нашу думку, при патріотичному вихованні є розуміння того, що чим раніше діти освоюють поняття, пов'язані з національною приналежністю, цивільною ідентичністю, нормами поведінки в соціумі, тим усвідомленішими та стійкішими будуть надалі їх громадянська позиція та патріотичний настрій.

\section{Список використаних джерел:}

1. Коваленко О. А., Жерновникова О.А. Виховання інтелектуальної еліти нації: зарубіжний та вітчизняний д освід. Рідна школа. 2021. Вип. 3. C. 25-29.

2. Гончаренко С. У. Український педагогічний словник. Київ: Либідь, 1997. $326 \mathrm{c}$.

3. 李道佳 幼儿爱国主义教育的基本原则《学前教育研究》,1995.1.21-22

4. 赵雪梅浅谈如何在少数民族聚居地区对幼儿进行爱国主义教育《师者讲坛》, 2015. 3. 15-16. 